\title{
ЗАСТОСУВАННЯ ПРИНЦИПІВ СИСТЕМНОГО АНАЛІЗУ ДЛЯ РАЦІОНАЛІЗАЦІЇ ФУНКЦІОНУВАННЯ ПРИПОРТОВИХ ВАНТАЖНИХ СТАНЦІЙ $З$ ОБСЛУГОВУВАННЯМ КОНТЕЙНЕРНИХ ВАНТАЖОПОТОКІВ
}

\section{THE APPLICATION OF SYSTEMATIC ANALYSIS PRINCIPLES ON THE FUNCTIONING OF PORT FREIGHT STATIONS WITH CONTAINER FREIGHT TRAFFIC PROCESSION}

\author{
Представив д-р техн. наук, професор С.С. Альошинський
}

\begin{abstract}
Постановка проблеми. Згідно зі Стратегією розвитку залізничного транспорту на період до 2020 року, одним iз напрямків ऑii реалізації $\epsilon$ поліпшення економічної стабільності галузі. В умовах збільшення вантажообігу на залізницях останніми роками та, зокрема, зростання експортно-імпортного вантажопотоку виникає необхідність відповідності технологічної схеми організації роботи припортових станцій та їх технічних потужностей саме експортно-імпортному характеру переробки вантажів.
\end{abstract}

Стабільне зростання міжнародної торгівлі дозволяє морським торговим портам нарощувати вантажопереробку, зокрема у контейнерному способі перевезення вантажів, і залучати зарубіжні інвестиції для розвитку портових перевантажувальних комплексів у той час, коли на залізницях таких можливостей практично немає.

Останніми роками значно розширилася номенклатура вантажів, що вивантажуються у морських портах. Намітилась тенденція зростання обсягів контейнерних перевезень через морські порти 3 перевалкою на залізничний транспорт. В результаті на залізниці різко збільшилися обсяги сортувальної та маневрової роботи 3 підбірання й розстановки вагонів на багатьох фронтах $\mathrm{i}$ дільницях портів. Морські торгові порти при збільшенні своїх потужностей повинні отримати технічні умови від залізниці для розвитку залізничної інфраструктури припортових станцій. Але надані залізницею технічні умови не завжди відповідають реальним обсягам вантажу, що надходить, через невідповідність технічного оснащення сучасному рівню й характеру вантажоперевезень та відсутність такої технології роботи, яка б була орієнтована на управління місцевими потоками вантажів 3 урахуванням специфіки та впливу кожної складової на загальний результат транспортного процесу.

Аналіз останніх досліджень i публікацій. Значний внесок у розробку організації технологічного процесу вантажних перевезень 3 метою підвищення рівня взаємодії різних видів транспорту, транспортного та інформаційного забезпечення зробили дослідження вчених Дьоміна Ю.В., Кірпи Г.М., Козлова В.Є., Котенка А.М., Нагорного Є.В., Негрея В.Я., Персианова В.О., Повороженка В.В., 
Полякова А.О., Смєхова А.О., Топчієва М.П., Яновського П.О. та інших видатних вчених.

Мета дослідження: Великі обсяги місцевої роботи, а також значна частка експортно-імпортних перевезень, що організовуються у взаємодії 3 іншими видами транспорту, i, в першу чергу, 3 морським, визначають особливості функціонування залізничних перевезень на припортових станціях. Вони вимагають не тільки застосування типових технологічних рішень 3 організації транспортного процесу, але й розробки технологій, що враховують специфіку роботи окремих вантажних напрямків. Тому наразі $€$ актуальним пошук ефективної технології місцевої роботи припортових станцій 3 виконанням операцій 3 контейнерними вантажами, що взаємодіють 3 морськими портами. Основною метою дослідження $є$ розробка методології системного аналізу функціонування виділених у систему об'єктів 3 обслуговування універсальних контейнерних вагонопотоків для виявлення поведінки та ефективності системи за допомогою математичної та імітаційної моделей.

Основна частина. Досягнення рівня комплексної та високоефективної мережі контейнерних перевезень, як на внутрішньодержавному, так i на міжнародному рівнях, означає необхідність усунення бар'єрів для швидкого i безперешкодного переміщення вантажів. Однією 3 виконавчих ланок процесу переміщення контейнерних вантажів $\epsilon$ безпосередньо припортові вантажні станції, що здійснюють основну перевалочну роботу з вантажами, які надходять до портів, та відповідну сортувальну роботу 3 підбору вагонів за окремими районами i причалами порту згідно зі спеціалізацією вантажних фронтів та формуванням маршрутів і передавальних поїздів до сортувальної станції.

На сьогодні склалася ситуація, при якій переробна спроможність припортових станцій і пропускна спроможність дільниць на підходах до портів не відповідає переробній спроможності портів. Така диспропорція між пропускною спроможністю станцій і переробною спроможністю портів продовжує збільшуватися. Тому на сьогодні необхідно залучення капіталовкладень для розвитку припортових залізничних вузлів і ліквідації диспропорції між ними i портовими терміналами.

Процес взаємодії припортових вантажних станцій та опорних сортувальних станцій при здійсненні перевізного процесу у відношенні контейнерних вантажів необхідно розглядати 3 позиції раціоналізації часу знаходження вагонів 3 контейнерними вантажами на припортовій вантажній станції з метою прискорення обігу вагонів та ефективного використання спеціального вагонного парку для транспортування контейнерів. При рішенні питання удосконалення технології роботи припортових вантажних станцій та взаємодії їx із сортувальними до розгляду слід прийняти не лише ті поїзди, що надходять у переробку до сортувальної станції, а й контейнерні маршрутні поїзди. Хоча такі поїзди не заходять до сортувальної станції, але для їх обслуговування необхідні оснащені термінали на припортових вантажних станціях, оскільки вони $є$ кінцевими пунктами прямування таких маршрутів.

Найбільший вплив на технологію виконання операцій із составами поїздів і вагонами надає нерівномірне надходження поїздів у переробку до сортувальної станції, де певний технологічний темп переробки вагонів залежить від наявної переробної спроможності сортувальних пристроїв і виділених маневрових засобів. Якщо інтервал між розбірними поїздами, що надходять в переробку, більше гіркового технологічного інтервалу, то створюється резерв у використанні маневрових засобів i сортувальних пристроїв. Якщо інтервал прибуття менше 
гіркового технологічного інтервалу, то цей резерв швидко зменшується. До того ж, через великі непродуктивні простої при зайнятості всіх колій приймання в парку прибуття неможливо прийняти розбірні поїзди, які простоюють біля вхідного світлофора або їх вимушені залишати на проміжних станціях.

Одним 3 важливих резервів скорочення простоїв вагонів на вантажних станціях $\epsilon$ скорочення часу переробки вагонопотоків, що надходять 3 сортувальних станцій в результаті скорочення кількості груп вагонів, що проходять повторний підбір за вантажними фронтами станції та порту. Відомо, що швидкість розпуску составів на сортувальній гірці знаходиться у зворотній залежності від кількості відчепів в ньому, тому величина відчепа суттєво впливає на тривалість виконання операцій розформування-формування поїздів. Більш детальний підбір груп вагонів окремо за вантажними фронтами при здійсненні сортувальної роботи на сортувальній станції дозволить скоротити час на переробку вагонів на вантажній станції.

У свою чергу це суттєво прискорить час на переробку вагонопотоків внаслідок того, що збільшиться середня величина відчепа на вантажній станції, оскільки сортування вагонів буде проводитись лише за коліями призначення кожного відчепа, а не кожного вагона окремо.

Як система до розгляду приймається фізична сукупність об'єктів 3 обробки вагонопотоків для перевезення універсальних контейнерів, що складається 3 припортової вантажної станції 3 обслуговуванням універсальних контейнерних потоків та порту, що знаходиться у безпосередній взаємодії із припортовою станцією (СС-ВС-П) (див. рисунок). Оскільки проблема скорочення часу простою вагонів, а як наслідок мінімізації витрат ресурсів, відноситься до усіх структурних підрозділів даної системи, то проблема у територіальному, функціональному та технологічному відношенні охоплює сукупність усіх об'єктів.

3 огляду на визначеність системи, що розглядається, необхідно виділити такі іï підсистеми (див. рисунок):

- опорна сортувальна станція;

- припортова вантажна станція.

Оскільки порт розглядається лише 3 позиції одного 3 кінцевих пунктів прямування досліджуваних вагонопотоків, доцільним $\epsilon$ виділення його як окремого елементу системи. Основними об'єктами $\mathrm{O}_{\mathrm{i}}$ станції є такі:

- парк прибуття $\left(\mathrm{O}_{1}\right)$;

- сортувальні пристрої - сортувальний парк $\left(\mathrm{O}_{2}\right)$;

- вантажні фронти станції $\left(\mathrm{O}_{3}\right)$;

- дільниця з'єднувальні колії - порт $\left(\mathrm{O}_{4}\right)$;

- парк відправлення $\left(\mathrm{O}_{5}\right)$.

Одним 3 центральних понять теорії систем $€$ поняття системи, визначене у теоретико-множинних термінах [2]:

$$
S \subset \otimes\left\{O_{i}, i \in I\right\}
$$

де $O_{i}$ - вага компоненти; $i \in I$ - декартова множина добутку $O_{i}$, що називається об'єктами системи $S t ; \quad I \quad-$ множина індексів.

Система функціонує у часі; у кожен момент часу система може перебувати в одному 3 можливих своїх станів. Процес функціонування відбувається як послідовна зміна станів системи $S_{t i}$ під дією зовнішніх і внутрішніх факторів.

Множину моментів часу $t_{i}$, у які розглядається функціонування системи, позначимо $T, t_{i} \in T$.

На вхід системи можуть надходити вхідні сигнали $v \in V_{t}$, де $V_{t}-$ множина вхідних сигналів системи. Відносно системи СС-ВС-П вхідними сигналами $є$ інформація про надходження у розформування поїздів 3 вагонами для перевезення контейнерів 3 сортувальної 
станції на адресу припортової вантажної станції та самі поїзди, що прибувають у парк приймання.

Система спроможна видавати вихідні сигнали $w \in W_{t}$, де $W_{t}-$ множина вихідних сигналів системи. Вихідний сигнал, що видається системою в момент часу $t \in T$, позначається $w_{i}$. Для системи, що розглядається, вихідними сигналами $\epsilon$ відправлені поїзди формування вантажної станції.

Стан системи в даний момент часу $S_{t}$ визначається попередніми станами та вхідними сигналами, що надійшли в даний момент часу й раніше. Вихідний сигнал у даний момент часу визначається станами системи та вхідних сигналів, що відносяться до даного й попереднього моментів часу. Ці два припущення відображають реакцію системи на внутрішні фактори й впливи зовнішнього середовища: післядію й принцип фізичної спроможності до реалізації.

Стан системи з обробки залізничних контейнерних вагонопотоків $S_{t}$ в момент часу $t$ можна задати виразом

$$
S(t)=h\left(S_{0 t} ; t ; V_{t} ; W_{t} ; R_{t}\right),
$$

де $h$ - вектор стану системи;

$S_{0 t}$ - початковий стан системи;

$t$ - час моделювання;

$V_{t}$ - вхідні сигнали системи;

$W_{t}$ - вихідні сигнали системи;

$R_{t}$ - ресурси системи.

Внутрішню зміну стану системи $S_{t} 3$ певними умовами необхідно розуміти як обмін та перерозподіл ресурсів $R_{t}$. Згідно з класифікацією, запропонованою у [3], як ресурси системи розглядаються такі: експлуатаційні ресурси парку рухомого складу та його окремих одиниць $M_{t}$ (вагони для перевезення контейнерів, що знаходяться у кореспонденції припортової вантажної станції, на адресу сортувальної станції або порту), паливно-енергетичні ресурси $P_{t}$ (витрачене паливо при виконанні маневрової роботи на сортувальній та вантажній станції) та виробничі ресурси обладнання, цивільних споруд та інших видів основних фондів ремонтних підрозділів $B_{t}$ (колійний розвиток, технічні механізми для обслуговування вагонів).

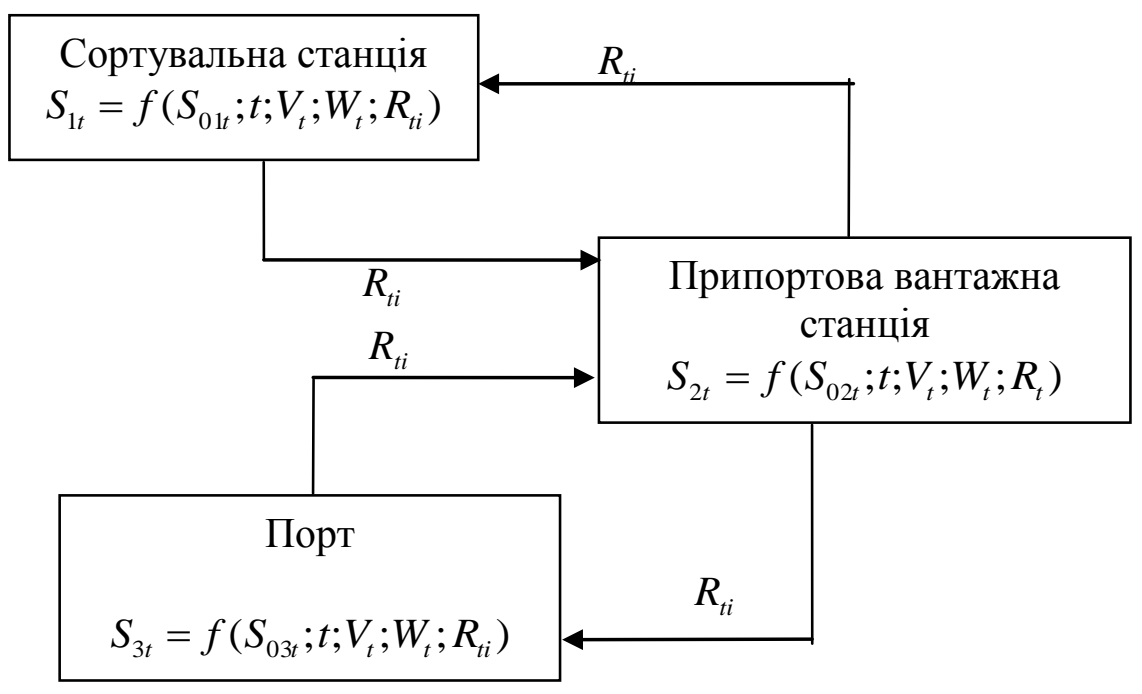

Рис. Загальна структурно-функціональна схема взаємодії складових системи СС-ВС-П 
Вихідними даними задачі оперативного управління функціонуванням системи СС-ВС-П $є$ інформація про структуру системи, про значення технічних характеристик елементів системи, до яких відносяться кількість колій у парках станцій та на вантажних фронтах 3 їх оснащенням навантажувальнорозвантажувальними механізмами, кількість працюючих маневрових локомотивів й оперативна інформація про стан системи у попередні моменти часу $t_{0}-2, t_{0}-1, t_{0}$. Розрахунок параметрів кожного режиму функціонування здійснюється у момент часу $t_{0} 3$ випередженням $1,2,3, \ldots, t, 3$ урахуванням вимог щодо припустимості режиму. Як критерій оптимізації режиму функціонування будемо розглядати адитивний критерій мінімуму експлуатаційних витрат на обробку вагонів
3 контейнерами, що надходять у систему СС-ВС-П [4].

Висновки. У реальних умовах процесу переробки вагонопотоків для перевезення контейнерних вантажів виникають ситуації невизначеності, які не піддаються вимірам й автоматичній ідентифікації. Управлінський (черговий i диспетчерський) персонал приймає рішення, користуючись досвідом, інтуїцією й оцінкою лінгвістичних змінних.

Застосування принципів системного аналізу дає можливість визначення раціональних режимів функціонування системи, що розглядається, для створення автоматизованого робочого місця управлінсько-виконавчого персоналу комплексу, який в реальному часі дозволяє приймати технічно та технологічно обгрунтовані рішення щодо процесів обробки вагонопотоків для контейнерних перевезень.

\section{Список літератури}

1. Транспортна стратегія України на період до 2020 року. Схвалена розпорядженням Кабінету Міністрів України від 16 грудня 2009 р. №1555-р: [Електронний ресурс]. - Режим доступу: www/URL: http://www.mintrans.gov.ua/ uk/discussion/15621.html/ 10.12.2009. - Загол. з екрану.

2. Матвеев, Ю.Н. Основы теории систем и системного анализа: учеб. пособие [Текст]/ Ю.Н. Матвеев. - 1-е изд. - Тверь: ТГТУ, 2007. - 100 с. - Ч. 1.

3. Данько, М.I. Наукові основи ресурсозберігаючих технологій при організації вантажних залізничних перевезень [Текст]: автореф. дис. ... д-ра техн. наук: 05.22.01 / M.I. Данько: [Харк. нац. акад. міськ. госп.]. - 2005. - 40 с.

4. Шелехань, Г.І. Математична постановка задачі раціоналізації функціонування припортової вантажної станції [Текст]/ Г.І. Шелехань // Вісник науковця. Науковопопулярний журнал. - 2010. - № 1. - С. 167-171.

Ключові слова: системний аналіз, припортова вантажна станція, контейнерні потоки.

\section{Анотації}

Розглянуто питання відповідності технології роботи припортових вантажних станцій 3 переробкою контейнерних вантажопотоків сучасному експортно-імпортному характеру переробки вантажів. Визначено функціонування таких станцій за допомогою системних принципів. Виділено основні характеристики системи 3 обслуговування контейнерних вантажопотоків та побудовано загальну структурно-функціональну схему взаємодії iі підсистем. 
Рассмотрены вопросы соответствия технологии работы припортовых грузовых станций с переработкой контейнерных грузопотоков современному экспортно-импортному характеру переработки грузов. Определено функционирование таких станций посредством системных принципов. Выделены основные характеристики системы обслуживания контейнерных грузопотоков и построена общая структурно-функциональная схема взаимодействия ее подсистем.

The problems of port freight stations with container freight traffic procession working technology according to the modern export-import character of processing of loads are considered. functioning of these stations by means system principles is certain. basic descriptions of the with container freight traffic procession system are selected and it was built the general structuralfunctional diagram of co-operation of its subsystems. 